\title{
Iran And Yemen; Study the Reflection of The Islamic Revolution of Iran On Yemen And Its Results
}

\author{
Amir Reza Emami* and Fatemeh Zare
}

Department of Law and Political Science, Faculty of Social Sciences and Humanities, Yazd, Yazd University, Iran

\section{ARTICLE INFO}

\section{Keywords:}

Iran

Yemen

Islamic Revolution

Reflection

\begin{abstract}
The Islamic Revolution of Iran took place in 1789. Undoubtedly, this revolution had repercussions on its peripheral and semi-peripheral countries, and one of the semi-peripheral countries of Iran that were affected by the revolution was Yemen. Yemen changed with the beginning of the Arab Spring and protest movements were formed in it, the content of which was very close to the foundations of the Islamic Revolution of Iran. These protests led to the revolution and eventually to the victory of the Houthi movement in Yemen and the Ansar Allah movement. But what are the consequences of this event in Yemen in Yemen and the Islamic Republic of Iran? The purpose of this study is to check the results of the export of the Iranian revolution in Yemen. The research findings show that the Islamic Revolution of Iran was exported to Yemen and a very close relationship was established between Yemen and the Islamic Republic. The Yemeni revolution has had very positive results for the regime of the Islamic Republic of Iran, like the addition of Yemen to the axis of resistance, resistance to Saudi Islam, etc., but to the results that happened to Yemen itself, we can become independent. Yemen touched on freedom of action in deciding and choosing its destiny. Yemen is embroiled in a bloody war that is still going on, and the living and economic situation of the people in Yemen is worse than before. The method of the present study is qualitative and based on the analytical description.
\end{abstract}

\section{Introduction}

The outbreak of the Islamic Revolution in 1979 in Iran became the source of dramatic changes in the world, including the Islamic world. Due to its religious and cultural face, this revolution was able to break even the boundaries of the theories of the revolution, and experts in the discussion of the revolution, including Ms. Teda Skocpol, moderated their theories (Skocpol, 1982). Some people, including Robin Wright, even refer to it as the Great Revolution (Wright, 2000). The first and most important factor that led to the Iranian Revolution being considered as the Islamic Revolution was the Islamic ideology and its spiritual and non-spiritual leaders who proposed it. Thus, this revolution was the first example of a successful revolution inspired by Islam (Esposito, 2014).

The Islamic Revolution had a great impact on attitudes, ideas, actions and behaviors in the region and the world, and undoubtedly had consequences and repercussions that affected the countries around and semi-surrounding Iran. Yemen is one of the most important semiperipheral countries in Iran that was affected by the Islamic Revolution of Iran. This country, which is located in the south of the Arabian Peninsula, has a special and strategic position in terms of history, culture, geopolitics, etc. Between 30 and 35\% of the country's population is

*Corresponding Author E-Mail Address: Amirrezaemami93@gmail.com, Amirreza.Emami1993@outlook.com 
made up of Zaidiyyah Shia. With the outbreak of the Tunisian revolution and the beginning of the crisis in the Arab countries, which is known as the Arab Spring or the Islamic Awakening, Yemen also became involved in internal conflicts and the revolution, which is still involved in some way.

\section{Research Method}

The present study is a qualitative research. Qualitative research has a holistic, interpretive approach and is done for exploration in a natural context and should not be done in an artificial range. Qualitative research acquires information about life, culture, value, ideological and behavioral principles, language, feelings, emotions and beliefs of people. A qualitative researcher collects information using regular methods, thinks about its meaning and concept, concludes, evaluates them, and finally presents them. The research environment is in fact the real world in which research and study take place. This environment is studied as a whole and its analysis into components and study of components is avoided. In qualitative research, the researcher who plans to collect the data must be consistent with the type of information he or she seeks. The researcher can use three strategies of in-depth interview, observation and sampling in his research. But we can also refer to the study of documents, graffiti, library resources, in general, stable and unstable documents (Abedi and Shavakhim, 2010).

The present study is based on a descriptive approach to analysis. In this type of research, in addition to illustrating what is, the researcher explains the reasons for how it is and why the problem and its dimensions. The researcher needs a strong argumentative basis to explain and justify the reasons. This support is provided by searching the literature and theoretical topics of research and compiling general propositions and theorems about it, which are usually compiled in the chapter on backgrounds and theoretical topics of research. One of the characteristics of descriptive research is that the researcher does not interfere in the position, situation and role of variables and does not manipulate or control them, and only studies what exists, describes it. Descriptive research may lead to the discovery of laws and the presentation of theories; this means that general knowledge is gained through such research. For example, when the characteristics of a particular phenomenon or subject are carefully studied and identified, these characteristics can be generalized to similar cases and a general theorem can be presented.

In another way, it is possible to achieve general cognitions and theorems through descriptive research and that is the use of inductive method; This means that when a common and uniform feature or attribute is repeated and observed in various phenomena and objects, a theory can be presented based on it. Therefore, according to the above explanations, the method of the present research is qualitative and based on analytical descriptive, the method of data collection and information is based on documentary studies, libraries and reputable research and extension science journals and various statistics.

\section{Theoretical Framework}

\subsection{Broadcast theory}

It seems that the best theory in which the reflection of phenomena can be observed is the theory of diffusion. This theory is also very suitable for explaining the export of the revolution (Barzegar, 2012). This theory was invented by Hager Strand (Swedish geographer) in 1953. Through this theory, he sought to find out how to spread innovation in the field of agricultural phenomena and bovine tuberculosis over the years. According to Shakuie, this theory later dealt with how cholera spread in different regions such as India, Central Africa, the Middle East, etc. (Shakuie, 2010).

Although it was the starting point of its application in agricultural phenomena and the spread of diseases, its application spread to other cultural fields. 
In sum, this theory explains the spread of any kind of intellectual or physical innovation; Such as the justification for the dominance of shorts or shorts. It was first introduced to the world in the spring of 1970 in Paris and in the autumn of the same year quickly spread from Sydney boutiques in Australia to San Francisco in the United States. Therefore, this theory has the power to explain any mental or physical innovation. Explains the reason for its spread, the manner of its spread and its routes and channels of distribution, as well as the reasons for its cessation and the reasons for its re-expansion, as well as the stability of some waves and the decline of others (Barzegar, 2012). In general, dissemination is a process according to which a cultural matter (an institution or a technical invention, etc.) that is the hallmark of one society, is borrowed in another society and accepted by that society (Barzegar, 2012). Distribution includes types such as displacement, contagion, and hierarchy; In hierarchical distribution, phenomena are transmitted and propagated through a regular sequence of categories and classes. Ideas spread from person to person or from one urban center to another (Barzegar, 2012).

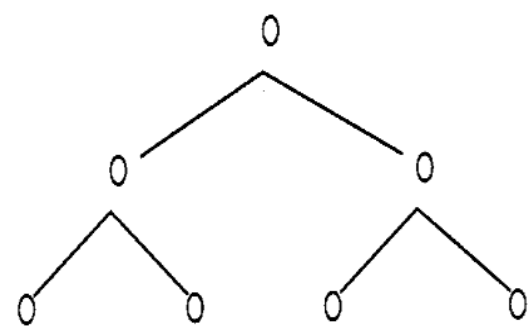

Figure 1. Hierarchical distribution

Source: (Barzegar, 2012)

In broadcasting, the general spread of ideas takes place without regard to hierarchy;

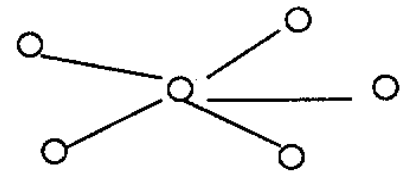

Figure 2. Infectious broadcast

Source: (Barzegar, 2012)

In fact, this type of broadcasting is opposed to hierarchical broadcasting. This type of broadcast is strongly influenced by distance. There are two types of hierarchical and contagious. The type of broadcasts that are expansion type with high propagation speed (Barzegar, 2012).

In displacement broadcasting, the prerequisite for broadcasting is an innovation or an element of culture, the transmission of an individual or group carrying an idea. Displacement displacement occurs when individuals or groups with a specific idea physically move from place to place. In this way, innovations and innovations are spread in the new land; Examples include the spread of religions with the dispatch of missionaries, the colonization of Europeans from 1500 to 1950, and the emigration of European Christians to the United States (Jordan and Rowntree, 2001). In a general and brief category, the factors of broadcast theory can be presented as follows: 


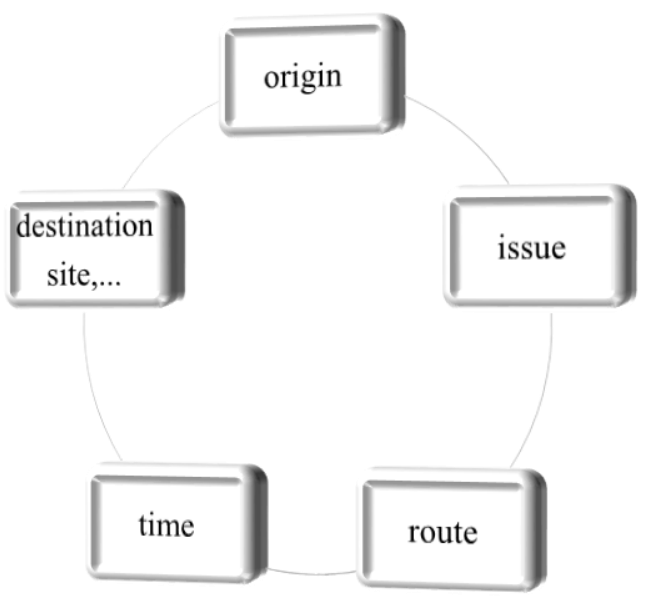

Figure 3. Five main factors in diffusion theory Source: (Shokuei, 2010)

Of course, other factors can also be highlighted in this theory, such as: propagation speed and factors affecting it, obstacles and borders and rival waves, predicting the effects of propagation and its harmful or useful from the point of view of the parties involved, as well as countermeasures (Shokuei, 2013).

But the definitions of each of these components are brief;

Origin: Places that are the origin of innovations and messages and values and innovations.

Destination, domain and place: Destination means the places to which the broadcast content or the continuous streaming stream reaches. The geographical area or environment can be receptive (convergent) or non-environmental (divergent) (Shokuei, 2010). In defining the place, it can be specified that the main goal is in the destination.

Time: is a factor that can be considered continuously or in the form of distinct periods from each other and consecutively. The starting point and evolution of phenomena are denoted by $\mathrm{T}$. its periods by $\mathrm{t} 1, \mathrm{t} 2$ and $\mathrm{t} 3$.

Direction: Movement of phenomena and channels of transfer of innovation from origin to destination, geographical distribution and socio-economic distance are important issues in relation to phenomena.

Topic: The subject of the spread may be infectious diseases. Such as cholera, measles, influenza, bovine tuberculosis, agricultural and technological innovations like modified seeds or video, television, satellite. Cultural topics, such as rock and roll music, the prevalence of clothing models. Or physical-cultural phenomena, such as the revolutionary and guerrilla struggles of Russian peasants, Cuban revolutionaries, Vietnamese fighters, or black American ghettos (Shokuei, 2010).

\subsection{Features of play theory}

Selectiveness of cultural borrowing: When two cultures collide, after proving their usefulness and compatibility, certain elements and components are borrowed.

"Cultural borrowing" is a two-way street. It is not just civilized societies that influence primitive societies. Borrowed items often enter the culture of the destination community after being manipulated in the "original form". Some cultural features are "easier" to disseminate than others. Technological innovations are easier to accept than social and ideological ideas, because their degree of usefulness and usability can be recognized quickly (Ferraro, 2001). There are also factors in this theory that can reduce the speed of playback and they are referred to as "reducing factors" such as: 
Distance: The acceptance of cultural innovations also decreases with increasing distance. Innovations will be accepted more deeply and penetratingly at the point closest to the origin, and will diminish as they move away from it.

Time: The passage of time is also considered an important factor in this regard; Disseminating innovation to a farther point requires more time, as the number of acceptors decreases as the distance increases. Therefore, the rate of acceptance decreases with increasing time.

Barriers to seepage: In addition to the natural weakness and reduction of innovations and innovations due to the increase in time-distance, dams and obstacles also stop or slow down the process of innovation or stop further progress (Jordan and Rowntree, 2001).

\section{Findings}

4.1. Yemen

Yemen has a history of three millennia and has historically been one of the richest regions in the ancient world, as it was the link between India, China, Africa and the Mediterranean in trade. In the millennium BC, there were three centers of civilization in the Arabian Peninsula, the most important and most prosperous of which was in Yemen (Amirdehi, 2010). Due to its climatic features, which are located in a warm region, this land has a temperate climate, abundant monsoon rains and an abundance of blessings, which has long been known as "Saudi Arabia" (Yarshater, 2001) and was named after it. Because it is located on the right side of the Kaaba, it is called Yemen and its name is also derived from the root of Yemen (blessing) and also attributed to "Ayman ibn Yarab ibn Qahtan" (Al-Weisi, 1962).

\subsection{Geopolitical and geostrategic position}

Yemen is a country with an area of 527968 square kilometers with a population of about 24 million people, of which about $50.6 \%$ are men and $49.5 \%$ are women. Yemen is located in the south of the Arabian Peninsula and has wide sea borders in the Red Sea and the Gulf of Aden. The strategic position of the country in terms of aristocracy over the Horn of Africa and the possibility of controlling the movements of this region as well as the east coast of Africa through the maritime borders of southern and western Yemen and the island of Socatra, has given special importance to this country. In addition, the country's aristocracy over the Bab alMandeb Strait has given it double importance in terms of energy supply and transit of goods. In fact, a large percentage of the traffic on the Suez Canal also passes through Bab al-Mandeb. Therefore, it can be said that Bab al-Mandeb is as important as the Suez Canal (Drysdale and Blake, 1994). The existence of several factors has doubled Yemen's position in the twentieth century:

A. Its proximity to the Horn of Africa, which in the second half of the twentieth century has increased the sensitivity of its position due to the conflicts of superpowers in the region.

B. The siege of Bab al-Mandeb by Egyptian forces in the 1967 Five-Day War was a historic experience for the occupying regime in Jerusalem. Therefore, the security of Yemen is of vital importance to the Israeli regime.

C. Yemen, which shares borders with Saudi Arabia to the north, is particularly important for Saudi Arabia in terms of oil production and exports.

D. Due to having long beaches in the Red Sea and the Arabian Sea, as well as the existence of important ports such as Aden, Hodeidah and Faha, the strategic importance of Yemen doubles (Karimloo, 1995). In the picture below, you can see the Yemeni provinces; 


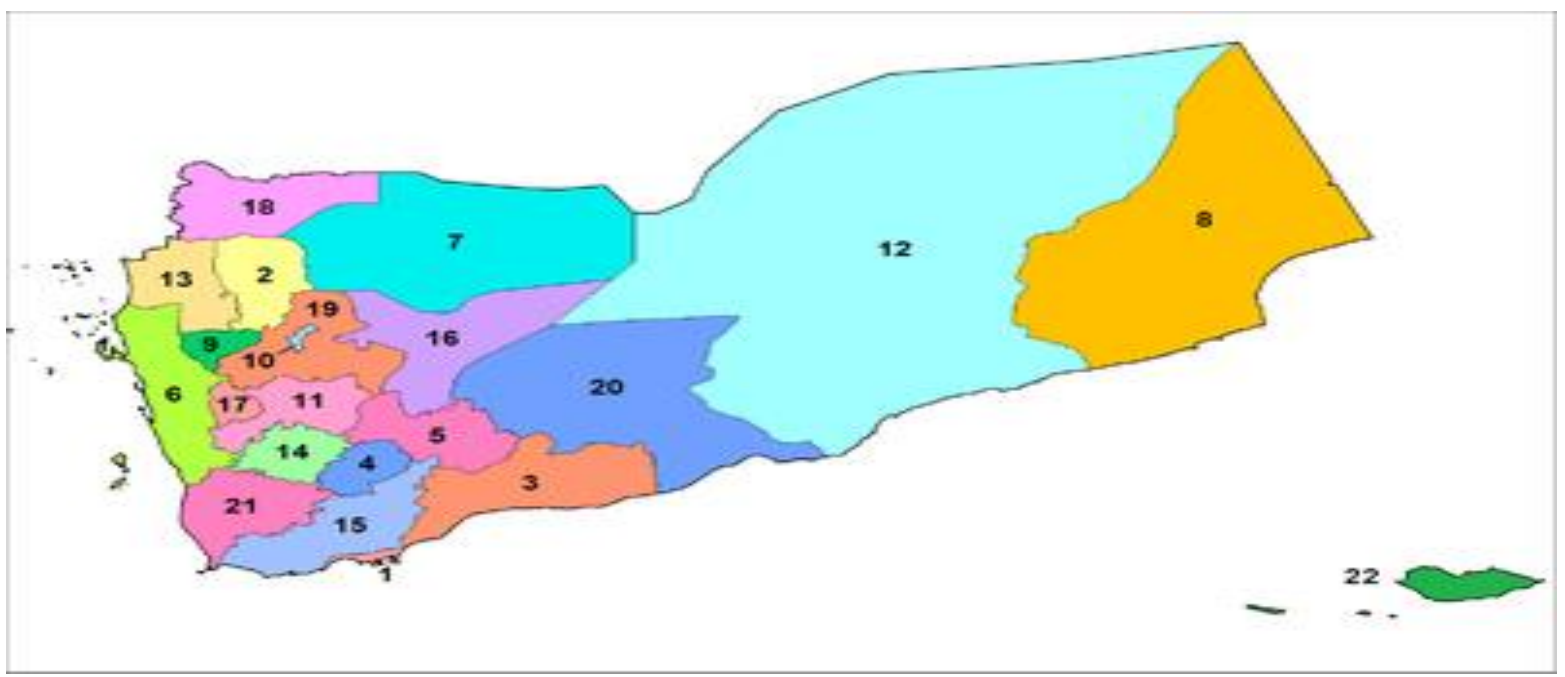

Figure 4. Provinces of Yemen

1_Aden. 2_Amran. 3_Abyan. 4_ Dhali'. 5_ Al Bayda. 6_Al Hudaydah. 7_ Al Jawf 8_ Al Mahrah. 9_Al Mahwit. Ewahit 10_ Amanat Al Asimah (Sana'a City). 11_ Dhamar. 12_ Hadhramaut. 13_ Hajjah. 14_Ibb. 15_Dhale. 16_Ma'rib. 17_Raymah 18_Saadah 19_Sana'a.20_Shabwah. 21_Taiz. 22_Socotra (Niakoee, 2012).

\subsection{Yemeni Shia population}

The official religion of Yemen is Islam. The Yemeni Muslim community is often religiously composed of the two religions of Zaidiyyah and Shafi'i. Zaydiyya came to Yemen in the second century $\mathrm{AH}$ and now most of the mountainous and northern regions of Yemen are inhabited and Sunnis who are mostly Shafi'i live in the south and in the coastal areas of "Tamameh" (Mir Razavi and Ahmadi Leforki, 2004). More than $99 \%$ of the people of this country are Muslims. Although there are no official statistics on the percentage of Shias and Sunnis in the country, it can be said that about $35 \%$ of the population are Shias and $65 \%$ are Sunnis.

Zaydiyya is one of the Shia sects named after Zayd ibn Ali. The followers of this sect, unlike the twelve Imams, consider Zayd ibn Ali as the fifth Imam instead of his brother, Muhammad Baqir, and in the Imamate of Ali ibn Abi Talib, Hassan ibn Ali, Hussein ibn Ali, Ali ibn Hussein (PBUH) with other Shias. Thus, if Shias are meant to mean "followers of Ali ibn Abi Talib (peace be upon them)", more than 35\% of Yemen's 26 million people are Shias, most of whom are Zaidis. It goes without saying that there are no exact statistics in this regard. Nevertheless, some believe that Zaidis make up 55\% of the population of Yemen (Abbasi and Golchin, 2015). The main center of the Zaidiyyah Shia in Yemen is Saada province, especially the city of Houth, but they also live in the provinces of Taiz, Al-Jawf, Sanaa, as well as in the provinces of Ab, Dhamar, Imran, Ma'rib, Hajjah, Mujawit and Hodeidah. Saada is the center of the Yemeni Ansarullah Shia movement. The province borders Saudi Arabia and is 243 kilometers from Sanaa and covers about 2.5 percent of Yemen.

\subsection{Overview of Yemen}

Yemeni society is a complex combination of tribal, sectarian, and religious divisions that have shaped the country's turbulent political life and Islamic revivalist environment. Prior to the unification of the two Yemenis in 1990, northern and southern Yemen were governed by completely different ideological regimes. The Arab Republic of North Yemen, established after the overthrow of the Zaidiyyah Hamid al-Din dynasty in 1962, took on a nationalist flavor under successive civilian and military regimes. Unlike in the north, there was difficult coexistence between Islam and the government in the Democratic People's Republic of South Yemen. Shortly after the independence of South Yemen in 1967, the Marxist regime took control of mosques, nationalized endowments, and replaced religious law with a non-religious 
law (Dekmejian, 2011). However, in the midst of the Cold War, northern and southern Yemen each tended toward a twentieth-century bipolar system; So that South Yemen was the arena of the Soviet Union and North Yemen was also in the hands of the United States, and the presence of these two powers created conflicts and imposed great costs on these two countries, which finally on May 22, 1990 together. Formed the ally and the Republic of Yemen. After the unification of the two Yemenis, the parliaments of the two countries elected "Ali Abdullah Saleh", the former president of North Yemen, as the president of the United Yemen, and "Haidar Abu Bakr al-Attis", the former leader of South Yemen, was appointed to form the government of the Republic of Yemen (Cigarettes, 1992).

Regarding Yemen's resources, it must be acknowledged that despite Yemen's underground resources and good geographical location, the country is still underdeveloped and poor. The reasons for this backwardness can be found in the existence of conflicts and civil wars, as well as the direct presence of superpowers in the past and large countries such as the United States and regional countries such as Saudi Arabia in recent years (Hashemi Nasab, 2009).

\subsection{Houthi movement}

There is a Shia group in the north of Yemen, in Saada province, which is attributed to Badruddin Houthi and is known as Houthis, and it is also called Shabab Momen group. The Faithful Youth Organization went through two stages; The establishment and formation phase, which began in 1990 and shortly after the announcement of the unification of the two Yemenis in some areas of Saada province in northern Sanaa, was limited to providing religious education to the youth and training and staffing. The Houthi centers became the Kaaba of the aspirations of many young people who went to Saada from different parts and other provinces. Gradually, the Houthis expanded their activities from Saada to other provinces and cities where the Zaydis lived. The second phase, which was the phase of armed confrontation against the government, began in 2004 (Doghshi, 2010).

The group was sponsored by Sayyid Badruddin al-Houthi and the group's chief of operations, Sayyid Hussein Badruddin al-Houthi, was an activist in the Shabab al-Momen group who was killed during the 2004 war with the Yemeni government (Sadeghi and Ahmadian, 2011). During his lifetime, Badruddin Houthi expressed his sincere devotion to Imam Khomeini, and this was to the extent that he was considered the representative of Ayatollah Khomeini in Yemen (Negahdar, 2017).

After him, his brother Abdul Malik al-Houthi, who had a strong intellectual, cultural and eloquent personality, was elected to lead the movement, despite the presence of his older brother Yahya. Since 2004 he has been leading the group. The Houthis had good and bad relations with the Yemeni government until 2003, and even the Houthis sided with the government in the 1994 secessionist war and fought the separatists with weapons and property provided by the government. In 2003, Ali Abdullah Saleh was warmly welcomed by young believers during a visit to northern Yemen. However, over time, the Yemeni government, concerned about the expansion of Houthi influence and power in the north of the country, set out to arrest their leader, Hussein al-Houthi, but this attempt led to six rounds of fighting between the Houthis and the Yemeni government, which failed without a victory. One-way ended.

\subsection{Iran-Yemen relations}

The relations between the Islamic Republic of Iran and Yemen during the last 40 years have always been a function of regional and international variables. Prior to the victory of the Islamic Revolution, the two countries of North and South Yemen did not have a clear definition and position in Iran's foreign policy. In particular, South Yemen was one of the allies of the Soviet Union, and this situation led to the Soviet military presence in the Red Sea and the Amman Sea 
and the dominance of the Bab al-Mandeb strategy, and the movement of Western military and merchant ships in these areas. Be disturbed, which was part of Iran's regional concerns at the time. Therefore, Tehran's foreign policy towards South Yemen in the second Pahlavi period was a worrying one. At that time, Iran deployed part of its military forces in Dhofar on behalf of the United States and the West to defend the kingdom of Amman. After the victory of the Islamic Revolution, we are witnessing a shift in the orientation of the foreign policy of North and South Yemen towards Iran. North Yemen was one of the first countries to recognize the Islamic Republic of Iran in 1979, but with the start of the Iran-Iraq War, North Yemen, led by Ali Abdullah Saleh, was influenced by the Gulf Cooperation Council and the Ba'athist regime invaded Iraq. Iran supported. North Yemen, which initially identified itself as a supporter of the Iranian revolution, even sent troops to the front during the imposed war to help the Ba'athist regime in Iraq. While South Yemen, led by Ali Nasser Mohammad, supported Tehran. On the other hand, the South Yemeni government, after the revolution, to show its goodwill, released an Iranian captive pilot who had been detained since 1967 due to the crash of his plane at the Dhofar border, through the mediation of the Oman People's Liberation Front (Amirdehi, 2010). Iran's involvement in the war with Iraq could not prevent the Islamic Revolution's discourse from influencing groups such as the Houthis in Yemen, whose currents of thought are influenced by the Iranian Revolution. Sayyid Hussein al-Houthi, the leader of this movement, in his speeches during his lifetime, constantly spoke about the innocence of the polytheists, Quds Day, the need to fight arrogance and the struggle against the Zionist regime; But the culmination was when the Houthis took control of Yemen in 2015 and Western-backed President Abd Rabbo Mansour Hadi was forced to resign in Sanaa and flee the capital. Many believed that with this internal development, Yemen had brought another Arab country under the control of Iran; But in this statement that the role of the Islamic Republic of Iran in the developments in Yemen is probably seen as a threat due to the increase of Iran's influence in the region, which is mostly raised by the Arab countries of the Persian Gulf (Mosavi and Bageri Far, 2015).

\subsection{Yemen and the Islamic Revolution of Iran}

The Islamic Revolution was the first event of the twentieth century to emerge outside the bipolar framework of the world; The United States and the Soviet Union had no role or influence in it. This event created a pervasive movement across the globe to revive Islamic principles and values (Bahmii, 2017). Following the victory of the Islamic Revolution in Iran, a new spirit of hope was breathed on the Muslims of the world, especially the Shias. This revolution could turn the protective currents of Islamic labor into revolutionary currents and lead to the creation of a wave of Islamic awakening. Yemen is one of the countries where the victory of the Islamic Revolution of Iran sparked hope and Islamic awakening among the Shias, including the Zaidis and the Houthi movement. Martyr Hussein al-Houthi, the leader of this movement, founded the core of the Islamic resistance in Yemen, influenced by the victory of the Islamic Revolution, familiarity with the personality and ideas of the leader of the Islamic Revolution. Therefore, the welcome of the Islamic Revolution of Iran in Yemen caused the Shia forces to become more active and in return, some of you saw your interests and survival in threat. (Shokrzadeh Chaharborj and Jafari far, 2019).

With the victory of the Islamic Revolution of Iran, the Zaidis send a delegation from Yemen to Iran and they appoint Imam Khomeini as their Imam. The word "Imam" is used only for Shia Imams, but with the use of this word, a great political closeness was created between the Zaidis and the Islamic Republic (Ganjkhani, 2017). However, under the influence of the Islamic Revolution of Iran, Shia movements no longer have the position of their former conservatives and have greatly influenced the future developments in Yemen. Concerns that have emerged outside Yemen and from countries such as Saudi Arabia in the region about these internal 
developments in Yemen have ultimately led to a number of hard and soft measures to counter the infiltration of pro-Iranian Shias in Yemen and their rise to power (Shokrzadeh Chaharborj and Jafarifar, 2019).

\subsection{The reflection of the Islamic Revolution of Iran on Yemen and its consequences 4.8.1. The reflection of the Islamic Revolution of Iran on Yemen}

In expressing the influential contexts of the Islamic Revolution of Iran, one should pay attention to the cultural aspect of the Ansarullah movement, which can be examined in three axes. First, being a Shia and the presence of Shia principles in it. The second is to criticize the current situation, especially the protest against the secular activities of the Yemeni government to provide conditions for Wahhabi activists and the occasional Saudi and American interference in the affairs of Yemen. Third, promoting the ideas of Imam Khomeini and the Islamic Revolution of Iran in areas such as the struggle against the United States and Israel. Undoubtedly, the occurrence of the Islamic Revolution in Iran caused a new spirit to be breathed into the body of the Yemeni Shia Shias, who were mainly Zaidis. "If the Islamic Revolution in Iran had not taken place, the Zaydi religion would have disappeared in Yemen," said Issam al-Emad, a former Wahhabi mufti who converted to burial. Thus, it can be added that with the Islamic Revolution of Iran, not only did life return to Zaydia, but also the jihadist principles in the Yemeni religious culture became more colorful than before, and the Al-Houthi movement from the heart of the Shia groups in this country Become one of the most important religious political forces in Yemen.

One of the most influential people in Yemen who was influenced by Ayatollah Khomeini's thoughts was Sayyid Hassan al-Houthi, who later took over the leadership of Houthi. According to the distribution theory, it can be said that due to the cultural and historical proximity of Iran and Yemen, favorable conditions have been provided for the presence and influence of the Islamic Republic of Iran in this country (Amirdehi, 2010). This affinity can include; The Islamic nature of Yemen and the Islamic Republic of Iran, the existence of Shias in Iran and Yemen, the cultural and religious relations between the elites, jurists and people of Iran and Yemen, as well as the historical background of oppression and oppression of Shias away from the real political scene. Therefore, the existence of cultural and religious backgrounds between Abiran and Yemen is one of the most important factors increasing the impact of the Islamic Revolution's discourse of the Yemeni people, which can occur in other cultural dimensions. For example, another symbolic activity in Yemen that has been influenced by the Islamic Revolution of Iran is the change in religious ceremonies. The Zaidiyyah Shia community has gradually been influenced by some of the rituals of the Imami sect, such as the mourning of Ashura and the complete prayer. These ceremonies were not common among the Zaidis before the Iranian revolution, but now a large number of Zaidiyyah Shia have adopted the Iranian and Iraqi Shia methods. They are now mourning on the day of Ashura and have a deep tendency to recite the complete prayer and the keys of Al-Jannan (Mirahmadi and Ahmadvand, 2015).

The presence of the Zaidis in the Yemeni political structure could change and ultimately moderate the previous view of Yemeni foreign policy towards the Islamic Republic of Iran. In addition, most Yemeni citizens are interested in the Islamic Republic, and public support for the Ansarullah movement and the Houthi Shias indicates the export of the Islamic Revolution to this geopolitical area (Shamsini Ghiasvand and Ahmadvand, 2016). "It suffices to say that the movement of the Yemeni revolution is inspired by thought," said Yahya Mohammad, a political activist and member of the Ansarullah movement, in an interview with the International Quran News Agency (IQNA). Ayatollah Khomeini has started and the main demand of the revolutionaries to implement justice and democracy in the country is to cut off the hand of the world powers from Yemen and preserve independence (Mosavi and Bageri Far, 
2015). Mohammad Mansour, one of the Zaidiyyah leaders, says: "If it were not for the Islamic Revolution of Iran, there would not be a Zadi in Yemen now" (Abbasi and Golchin, 2015). Another dimension that should be noted is that the link between the values of Iran and Yemen has led to concerns about the existence of a common enemy, which has provided the ground for closeness between the two sides, especially in terms of security and defense (Rostami et al., 2018).

The events of 9/11 and the declaration of war on terrorism made the Yemeni government the most important ally of the United States in this war. The Yemeni government's accession to the United States in the fight against terrorism increased the presence of US military and security forces in Yemen during the secret visit of Israeli delegations to Sanaa. This provoked the protest of Hussein al-Houthi. In 2002, he called for a boycott of American and Israeli goods and chanted "Death to America" and "Death to Israel." Far, (Mosavi and Bageri Far, 2015).

\subsubsection{The theory of the spread and reflection of the Islamic Revolution of Iran on Yemen}

The two countries of Iran and Yemen, in addition to their special geopolitical, geostrategic and geoeconomic strategic position in the Persian Gulf region, also have religious, religious and cultural commonalities with each other, and these components have facilitated these relations. Also, other institutions and channels are needed to do the broadcasting work; Therefore, tools, individuals and institutions will naturally or voluntarily be the cause of the spread of thought in this regard. The main difference between the Yemeni people's revolution and the popular uprisings is that the Yemeni people have a closer view of the Islamic revolution and their understanding of the literature of the revolution is higher than that of other nations. In this regard, embassies or cultural consultations as well as institutions such as seminaries, radio, foreign students' association, World Assembly for the Rapprochement of Religions, education of Yemeni students in seminaries and universities in Iran, Imam's funeral, Quds Day or translation of Ayatollah books Khomeini, Ali Shariati, Shahid Motahari and Allameh Tabatabai, who provide the possibility of transmitting messages, are among the routes and centers of the Islamic Revolution (Heshmatzadeh, 2008).

The occurrence of a revolution in a land with a high strategic position has the most repercussions; Therefore, the influential power (cultural superpower) of Iran is important in this regard. Of course, Iran seeks to influence the cultural, political and religious elites and attract them to the revolution, to achieve the process of cultural dissemination in a hierarchical manner. And Lebanon has also spread (Barzegar, 2003). This is also conceivable for Yemen. During his lifetime, Badruddin Houthi expressed his sincere devotion to Imam Khomeini, and this was to the extent that he was considered the representative of Ayatollah Khomeini in Yemen (Negahdar, 2017).

One of the topics of contagious broadcasting is the spread of broadcasting topics to the closest strata, individuals and regions that are adjacent to change and innovation. Due to the proximity of Iran and Yemen and the existence of cultural and religious homogeneity and other commonalities, Neighborhood, Yemen should be the first country to be exposed to the storm of cultural developments in Iran and the revolution will spread there through the spread of infection (Hazbavi and Karimifard, 2016). One of the most important components in the form of transmission is the common Islamic ideology, which is the unifying factor of all Muslims in the world. Exporting values in a revolution is considered one of the main goals of that revolution. By transmitting values to other countries, including Muslim countries, informing them through mass media such as radio, press, books, cinema and propaganda institutions such as seminaries and the Islamic Propaganda Organization and other official bodies such as the Ministry of Islamic Guidance and the Ministry of Affairs It is foreign. According to the mentioned topics, in general, the following diagram can be drawn; 


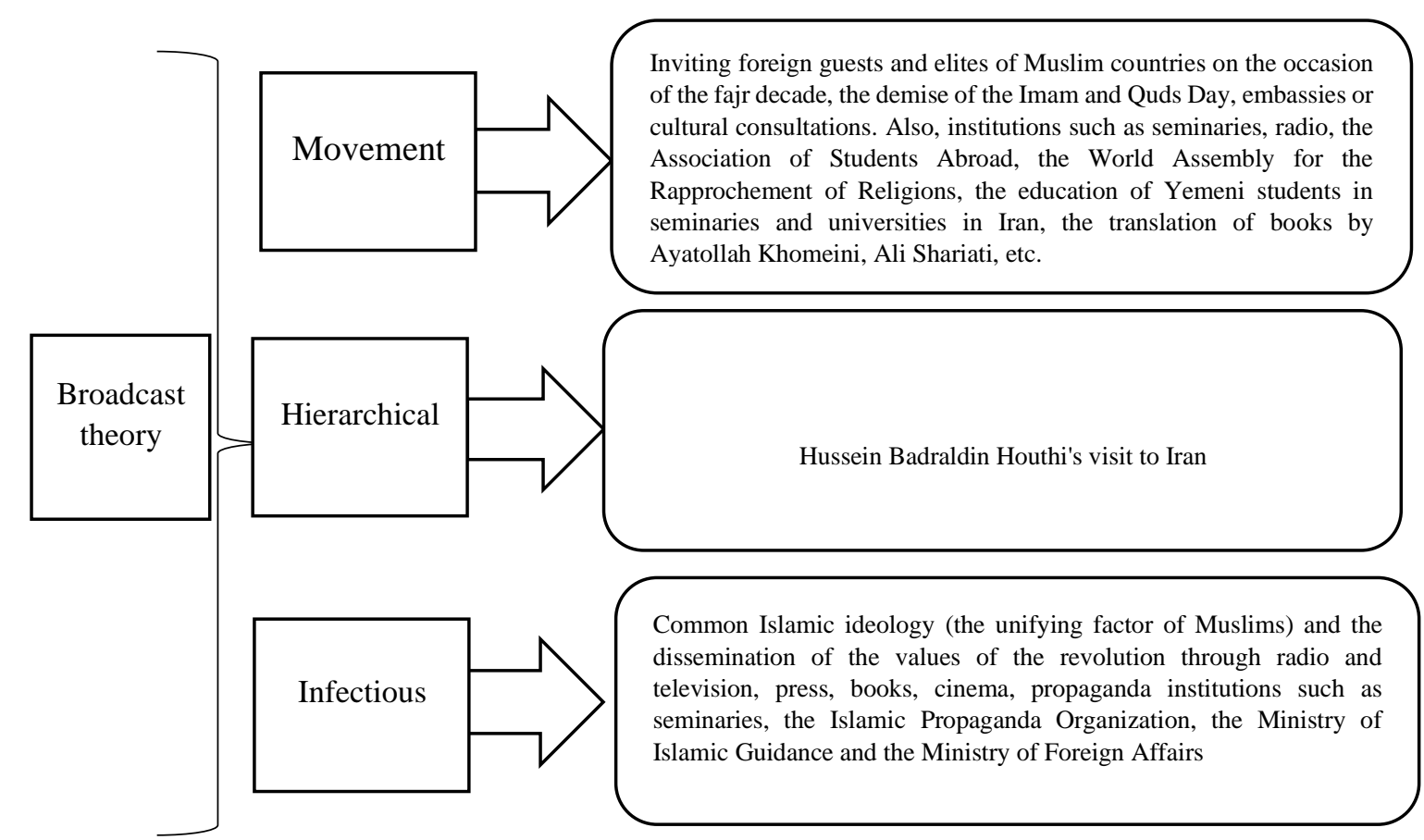

Figure 5. Theory of Dissemination and Reflection of the Islamic Revolution of Iran on Yemen Source: Authors of the present study

Now, according to what has been said, a table can be drawn in connection with the theory of diffusion and the Islamic Revolution as follows;

Table 1.

Factors of the theory of diffusion and the Islamic Revolution of Iran in Yemen

\section{Origin}

Destination, geographical environment and location

Time

Issue

Route (from origin to destination)

Obstacles

Predict playback effects
In the first place, Iran (Tehran) and in the second place, resistance movements in Iraq, Lebanon, Syria and Palestine (Nejat, 2018)

Yemen (Sanaa), largely (60\%) convergent with the principles and values of the Iranian revolution, the Houthi movement (Ansarullah of present-day Yemen) (Hosseini and Barzegar, 2013)

Early time in 1979 and over time (Shokouei, 1998)

Fundamentals of the Islamic Revolution (political, social and religious) Islamic Conference, Embassy of the Islamic Republic of Iran in Sanaa, Islamic Revolutionary Guard Corps, Cultural Counselors, Jihad Sazandegi, Ministry of Commerce, Seminary, Radio and Television of the Islamic Republic of Iran and the World Assembly of Islamic Religions (Barzegar, 2012)

The language and culture of the Yemeni people, lack of complete familiarity with the religious and social principles of Yemen, the repressive actions of Ali Abdullah Saleh, the efforts of Saudi Arabia and the coalition forces (Nejat, 2018)

Useful (Revival of Zaidiyyah Shia, influence of Yemeni personalities from the Iranian revolution, expansion of principles, foundations and rituals of the Twelver Shias and expansion of revolutionary and value slogans, Islamic awakening and increase of political demands (Nejat, 2018)

Source: Authors of the present study

\subsubsection{The consequences of the Islamic Revolution of Iran on Yemen}

According to the explanations in the previous sections, it becomes clear that Yemen, inspired by the Islamic Revolution of Iran (since the occurrence of this revolution until now) and being on the path of Islamic awakening (Arab Spring), has always demanded its independence, justice 
and freedom. In this direction, there are results for both Yemen and the Islamic Republic of Iran, the most important of which are the following;

- One can clearly see the spread and influence of the ideals, ideas and main principles of the Islamic Revolution of Iran to Yemen, and it can be acknowledged that Yemen became the axis of resistance against the United States, Israel and Saudi Arabia and their allies. Et al., 1396) in a way that opposition to the United States, Israel and Saudi Arabia and confronting them became the policy of the Yemeni movement (Shirkhani and Turki, 2017). Also, with the expansion of Shia geopolitics and the addition of Yemen to the axis of resistance, the alarm has been sounded for Saudi Arabia, whose religious foundations are Wahhabism (anti-Shia). Ansarullah, who was not recognized by Saudi Arabia and considered an armed and terrorist group, formed a ruling government, a government with management, and was able to manage the war and liberate the occupied territories, and position itself in the position of the peninsula and the region. The Red Sea should be visible and imposed, in fact, it should come out of an armed and terrorist group, as claimed by the Saudis, and become a regional government and actor.

- The main reason for the protests in the Arab Spring was the lack of democracy and political repression, the lack of freedom of expression, the lack of parties and political corruption (Niakoee, 2012). These factors were also observed in Yemen and led to the formation of many protests. Although the Yemeni protests were inspired by the Islamic Revolution of Iran, and with the capture of Yemen by Ansarullah, freedom and democracy were provided for the Yemenis in practice, it should not be overlooked that Yemen was embroiled in a bloody war that is still going on. In addition to the war, the economic situation and poverty in Yemen are worse than before, and the living conditions of the people are very poor. In this regard, we can refer to the statistics of the International Committee of the Red Cross, which according to the statistics provided by the Yemeni war, Yemenis in 2019 continue to suffer from hunger and malnutrition, and 3.2 million women and children are malnourished. Are severely affected (Irna, 2020).

\section{Conclusion}

The present study sought to examine the consequences of the reflection of the Islamic Revolution of Iran on Yemen. At first, using the theory of dissemination, it became clear that the Islamic Revolution of Iran, although late, was exported to Yemen. One of the main reasons why Yemen was a good platform for accepting the Iranian revolution is the existence of common religious beliefs. Yemen should be considered among the countries that, due to the common religious and doctrinal foundations with the Islamic Republic of Iran, its historical and cultural ties, as well as being in the geopolitics of the Islamic Awakening, was able to become president with his revolution inspired by the Islamic Revolution of Iran. To oust Yemen from power and cut off the hand of Saudi Arabia and the United States in the affairs of this country. But what were the consequences of the reflection of the Islamic Revolution on Yemen, which led to the formation of the Yemeni Revolution? The research findings show that the spread and influence of the ideals, ideas and main principles of the Islamic Revolution of Iran exist in Yemen and a very close relationship has been established between Yemen and the Islamic Republic. Also, considering the discourse of resistance that is rooted in the Islamic Revolution of Iran and the actions that Yemen took against Saudi Arabia and the coalition forces, it became clear that Yemen has been added to the axis of resistance against the United States, Israel and Saudi Arabia. Thus, the Yemeni revolution has had very positive results for the regime of the Islamic Republic of Iran, but in relation to the consequences for the Yemeni country itself, we can mention the independence of Yemen, freedom of action in deciding and choosing its own destiny. Yemen's Ansarullah, once considered a terrorist group by Saudi Arabia, is now recognized as an independent state and is able to manage the war to a great 
extent. Of course, this revolution also had bad consequences for Yemen. Yemen is embroiled in a bloody war that is still going on. In addition to the war, the economic situation and poverty in Yemen are worse than before, and the living conditions of the people are very poor.

\section{References}

Abbasi, Majid and Golchin, Saeed (2015). The Islamic Revolution of Iran and Shia Geopolitics in Yemen: From Identity to Awakening, Basij Strategic Studies Quarterly, 18 (69), 69_102. magiran.com/p1546007

Abedi, Ahmad and Shavakhim Alireza, (2010). The Comparison between Quantitative and Qualitative Research in Behavioral Science, Rahbord Journal, 19 (54), 153_168. magiran.com/p813064

Al-Weisi, Hussein bin Ali (1962). Al-Yaman Al-Kubra, First Edition, Ennahda Al-Arabiya Press, Egypt.

Amirdehi, Alireza (2010). Yemen from political rule to relations with the Islamic Republic of Iran, Thought Quarterly, 6 (23), 117_130.

Bahmii, Sajjad (2017). Theory of Dissemination and Impact of the Islamic Revolution of Iran on the Shias of Yemen, The First National Conference on Law and Political Science, Tehran, https://civilica.com/doc/807384

Barzegar, Ibrahim (2012). Theories of global reflection of the Islamic Revolution of Iran, Tehran: Imam Sadegh University.

Cigarettes, Norman (1992). Islam and the state in pre-union South Yemen, translated by Mohammad Javad Mahdavi, Mushkooh, No. 34.

Dekmejian, R. Hrair (2011). Islam in revolution: Fundamentalism in the Arab world, translated by Hamid Ahmadi, translated title: Islam in the Revolution: Contemporary Islamic Movements in the Arab World (Study of the Phenomenon of Islamic Fundamentalism), Sixth edition, Tehran: Kayhan Publishing Company.

Drysdale, Alasdair and Henry Blake, Gerald (1994). The Middle East and North Africa: A Political Geography, translated by Darreh (immigrants) Mir Haider, Tehran: Ministry of Foreign Affairs.

Esposito, John L. (2014). The Iranian revolution: its global impact, translated by Mohsen Modir Shane chi, Fifth Edition, Tehran: Center for the Recognition of Islam and Iran (Baz).

Ferraro, Gary P (2001). The cultural dimension of international business, translated by Ghulam Ali Shamloo, translated title: Cultural Anthropology: The Cultural Dimension of World Trade, Tehran: Samt.

Ganjkhani, Ahmad (2017). Yemen's ansar Allah movement and its relation with Iran's Islamic revolution, Master Thesis, University of Islamic Education, Department of Islamic Revolution.

Hashemi Nasab, Saeed (2009). Meeting on "Recent Developments in Yemen", Religious epistemology in the international arena Bi Quarterly Scientific-Specialized Research Institute of Regional Studies, 2 (2), 280_300.

Hazbavi, Khaled and Karimifard, Hossein (2016). Effluence Theory and the Influence of Iran's Islamic Revolution on Shiites in Bahrain, a Quarterly Journal of Political Studies of Islamic World, 5 (18), 189_206. 
Heshmatzadeh, Mohammad Baqer (2008). The Impact of the Islamic Revolution of Iran on Islamic Countries, Tehran: publishing organization of institute for Islamic culture and thought.

Hosseini, Seyyed Muhammad Sadeq and Barzegar, Ibrahim, (2013). Broadcast Theory and Islamic Revolution of Iran's Influence on Saudi Arabia, Journal of Islamic Revolution Studies, 10 (33), 173_188. magiran.com/p1129051

IRNA - Islamic Republic News Agency (2020). What happened to the Yemeni people in 2019 ? Available in www.irna.ir/news/83612195/.

Jordan, Terry G and Rowntree, Lester (2001). The human mosaic: a thematic introduction to cultural geography, translated by Simin Toulaei and Mohammad Soleimani, Tehran: Research Center for Culture, Art and Communication (Ministry of Culture and Guidance).

Karimloo, Davood (1995). Republic of Yemen, Tehran: Ministry of Foreign Affairs.

Mir Razavi, Firoozeh and Ahmadi Leforki, Behzad (2004). Guide to the region and the countries of the Persian Gulf, Tehran: Tehran International Studies \& Research Institute.

Mirahmadi, Mansour and Ahmadvand, Vali Mohammad, (2015). Identity and Intelletual Foundations of Ansarullh Movement, The Quarterly Journal of Political Thought in Islam, 1(2), 145_165. magiran.com/p1465706

Mosavi, Seyed Mohammad and Bageri Far, Mohsen, (2015). Constructive theoery and the reflection of Islamic revolution of Iran on ansarollah movement and revolution of yeman, Journal of Islamic Revolution Research, 4(14), 207_229. magiran.com/p1609341

Negahdar, Hamid Reza (2017). Geopolitical analysis of Shia religion in the convergence of Iran with Asian countries (Yemen case study), Master Thesis, Islamic Azad university Central Tehran Branch, Faculty of Literature \& Humanities -Department of Geography.

Nejat, Seyyed Ali, (2018). Reflection of the Islamic Revolution of Iran on the Ansarollah movement in Yemen, Middle East Studies Quarterly, 24(89), 115_140. magiran.com/p1890024

Niakoee, Seyed Amir (2012). The anatomy of contemporary Arab revolutions, Tehran: Mizan Legal Foundation.

Rostami, Farzad; Lotfi, Kamran and Pirmohamadi, Saeid, (2018). The Crisis in Yemen and the Regional Security Strategy of the Islamic Republic of Iran, Studies of International Relations Journal, 11(41), 9-35. magiran.com/p1841741

Sadeghi, Hossein and Ahmadian Hassan, (2011). Changing Yemen's Regional Status: Possibilities and Challenges, Rahbord Journal, 19 (56), 253_280. magiran.com/p812999.

Shakuie, Hossein (2010). Applied Geography and Geographical Schools, Eighth edition, Mashhad: Astan Quds Razavi.

Shakuie, Hossein (2013). New trends in philosophy of geography, Ninth Edition, Tehran: Institute of Geography and Cartography of Geology.

Shamsini Ghiasvand, Hassan and Ahmadvand, Mustafa (2016). The Impact of Regional States on Political Development of Yemen (2014-2015), Emphasizing on Saudi Arabia And Iran, journal of political and international researches.

shokrzadeh chaharborj, reza and jafari far, Ehsan, (2019). Reflection of the Islamic Revolution of Iran on Yemeni Shias, Pazuheshhaye Rahbordi Enghelabe Eslami, 1(4), 1-21. magiran.com/p2098877 
Shrkhani, Ali and Torki, Hadi, (2017). The Effect of Islamic Revolution on Yemenite Houthis, Journal of Islamic Revolution Studies, 14(50), 79-98. magiran.com/p1832150

Skocpol, Theda (1982), Rentier state and Shi'a Islam in the Iranian Revolution, Theory and Society, V. 11.

Wright, robin (2000). The last great revolution: Turmoil and Transformation in Iran, knopf, New York.

Yarshater, Ehsan (2001). History of Iran: From the Seleucids to the Collapse of the Sassanid State (Part II) (Volume 3), translated by, Hassan Anousheh, Tehran: Amirkabir Publishing. 